\title{
Leakage of $\beta$-Galactosidase from Phage-infected Escherichia coli: A Re-evaluation
}

\author{
By MYRIAM ISRAELI AND M. ARTMAN \\ Department of Bacteriology, Hebrew University-Hadassah Medical School, \\ Jerusalem, Israel
}

(Accepted 2 January 1970)

SUMM AR Y

Infection of Escherichia coli by bacteriophage $\mathrm{T} 4$ is not accompanied by leakage of $\beta$-galactosidase. Liberation of the enzyme, soon after infection, results from lysis from without. The nature of the lytic enzyme systems responsible for lysis from without is discussed.

\section{INTRODUCTION}

It is now generally accepted that normal infection of $E$. coli by $T$ even phage is accompanied by a noticeable increase in permeability of the host cell so that various cellular components, including large molecules such as the enzyme $\beta$-galactosidase, leak into the medium (Puck, \& Lee I955; Silver, Levine \& Spielman, 1968). The increase in permeability of the infected cell immediately after infection is believed to be caused by a limited digestion of bacterial cell wall initiated by the phage, the damage being independent of injection of DNA. The damage of the bacterial cell wall has to be repaired by resynthesis of the digested cell wall components before phage growth can proceed.

Most of what we know on permeability changes accompanying phage infection of $E$. coli has come from the work of Puck \& Lee (I955). The conclusion of the authors that leakage of small and large molecules from $E$. coli infected with moderate multiplicities of $\mathrm{T} 2$ phage is a reflexion of a true increase in cell permeability and of a necessary metabolic step are based on the results of two sets of experiments performed under widely different physiological conditions which are not entirely comparable. The leakage of small molecules $\left(\left[{ }^{32} \mathrm{P}\right]\right.$ and $\left[{ }^{35} \mathrm{~S}\right]$ ) was determined in $E$. coli cultures infected with $\mathrm{T} 2$ phage in nutrient broth, whereas the leakage of large molecules (RNA and $\beta$-galactosidase) was assayed after phage adsorption to $E$. coli suspended in buffered saline without nutrients. Thus, the leakage of small molecules was studied in the course of normal infection and that of large molecules under conditions where in some instances few phage particles adsorbed to a bacterial cell may evoke lysis from without (Heagy, 1950). In this communication we present evidence to show that leakage of $\beta$-galactosidase is not accompanying normal infection but results from lysis from without.

\section{METHODS}

Organisms. Escherichia coli $\mathrm{B}$, phage $\mathrm{T}_{4} \mathrm{~B}$ wild type and the lysozyme deletion mutant phage strain eG I9 (kindly supplied by Dr Emrich) were used.

Preparations of phages. $\mathrm{T}_{4} \mathrm{~B}$ phage grown on Escherichia coli were purified by differential centrifugation until they met the optical criterion of more than $2 \cdot 2 \times 10^{12}$ phage/extinction unit at $400 \mathrm{~nm}$. (Herriott \& Barlow, I952). High titre stocks of approximately ${ }^{10^{13}}$ p.f.u./ml. 
were stored in phosphate buffered saline over a drop of chloroform. Phage were assayed by the methods described by Adams (1959). Primary stocks of the lysozyme deletion mutant strain eG I9 were prepared with egg white lysozyme (Emrich \& Streisinger, I968). Phage stocks used in the experiments were prepared without egg white lysozyme as follows: a $100 \mathrm{ml}$. culture of $E$. coli $\mathrm{B}$, grown in tryptone broth to $5 \times 10^{8} \mathrm{cells} / \mathrm{ml}$. was infected with the eGI9 phage from the primary stock at the input multiplicity of 4 , and $15 \mathrm{~min}$. later superinfected with the same phage at the same input multiplicity. The culture was vigorously agitated at $37^{\circ}$ for additional $45 \mathrm{~min}$. A $10 \mathrm{ml}$. sample was assayed for the phage titre by the egg white lysozyme method and the remaining culture was centrifuged, the cells resuspended in $10 \mathrm{ml}$. of phosphate buffered saline, mixed with $26 \mathrm{~g}$. of 0.10 to $0.4 \mathrm{~mm}$. glass beads (Brown, Melsungen), disrupted for $10 \mathrm{sec}$. in the Bronwill mechanical cell homogenizer, filtered through coarse sintered glass and centrifuged at $6000 \mathrm{rev} . / \mathrm{min}$. for $5 \mathrm{~min}$. The phage titre in the supernatant fraction was assayed as described. Phage ghosts were prepared and assayed as described by French \& Siminovitch (I955).

Media. (I) Tryptone-Na $\mathrm{Na}^{+}$contained I \% (w/v) tryptone (Difco, Detroit, Mich., U.S.A.) and $0.5 \%(\mathrm{w} / \mathrm{v}) \mathrm{NaCl}$. Soft and hard agar for plating phage and bacteria contained tryptone$\mathrm{Na}^{+}, 0.13 \%(\mathrm{w} / \mathrm{v})$ glucose and $0.65 \%(\mathrm{w} / \mathrm{v})$ and $\mathrm{I} \cdot \mathrm{I} \%(\mathrm{w} / \mathrm{v})$ agar (Difco), respectively. (2) For plating the eG I9 strain, citrate-agar plates were used (Emrich \& Streisinger, I968). (3) M 9-L, for the induction of $\beta$-galactosidase, contained (per 1.): $5.5 \mathrm{~g}$. of $\mathrm{Na}_{2} \mathrm{HPO}_{4}$, 3 g. of $\mathrm{KH}_{2} \mathrm{PO}_{4}, 0.5 \mathrm{~g}$. of $\mathrm{NaCl}$, I g. of $\mathrm{NH}_{4} \mathrm{Cl}, 0.25$ g. of $\mathrm{MgSO}_{4} .7 \mathrm{H}_{2} \mathrm{O}, 0.0 \mathrm{I}$ g. of $\mathrm{CaCl}_{2}$ and 2 g. of lactose. (4) M9-G, M9-L supplemented with D-glucose instead of lactose. (5) Phosphate buffered saline contained: $0 \cdot 2 \mathrm{M}-\mathrm{NaCl}, \mathrm{IO}^{-4} \mathrm{M}-\mathrm{MgSO}_{4}$ and $\mathrm{IO}^{-3} \mathrm{M}$ phosphate buffer $\left(\mathrm{pH} 7^{\circ}\right.$ ) ) (Puck \& Lee, 1955).

Infection (Method $\mathrm{I}$ ). Escherichia coli $\mathrm{B}$ were grown overnight in $\mathrm{M} 9-\mathrm{L}$ at $37^{\circ}$. The overnight culture was diluted with the same medium and grown exponentially for 3 generations to $5 \times 10^{8}$ cells $/ \mathrm{ml}$. The cells were centrifuged at room temperature, washed with $\mathrm{M}_{9}-\mathrm{G}$ medium and resuspended in the same medium (containing tryptophan, I00 $\mu \mathrm{g} . / \mathrm{ml}$. medium) to the original cell density, incubated at $37^{\circ}$ for $5 \mathrm{~min}$., infected with varying input multiplicities of phage or ghosts and vigorously agitated for $2 \mathrm{~min}$.

Method 2. The cells were grown as described above, centrifuged at room temperature, washed with phosphate buffered saline and resuspended in the same buffer (containing tryptophan, $100 \mu \mathrm{g} . / \mathrm{ml}$.) at a cell density of $5 \times 10^{8}$ cells $/ \mathrm{ml}$. The cells were then incubated at $37^{\circ}$ or $4^{\circ}$ and mixed with phage or ghosts at varying input multiplicities. After $2 \mathrm{~min}$. of adsorption at $37^{\circ}$ or $20 \mathrm{~min}$. at $4^{\circ}$, more than $99 \%$ of bacteria were infected (at m.o.i. of 4 or higher). At intervals after adsorption the turbidity of the culture was determined by measurement of the amount of light scattered, the amount of $\beta$-galactosidase liberated into the surrounding medium was assayed by the method of Pardee, Jacob \& Monod (I959) and the appearance of spheroplasts was observed by means of phase contrast microscopy.

\section{RESULTS}

In order to determine whether normal infection causes leakage of $\beta$-galactosidase, soon after adsorption, Escherichia coli fully induced for $\beta$-galactosidase were grown in $\mathrm{M} 9-\mathrm{G}$, infected with T 4 phage or their ghosts (Method I) and the amount of the enzyme liberated after different times of infection was determined in the supernatant fractions of I ml. samples. Table $\mathrm{I}$ shows the results of a representative experiment. It can be seen that $10 \mathrm{~min}$. after the cells had been infected at 4 p.f.u./cell ratio the turbidity of the culture remained at the initial pre-infection level and the amount of $\beta$-galactosidase liberated by the cells was only 


\section{Table I. Leakage of $\beta$-galactosidase from $E$. coli infected with $\mathrm{T}_{4}$ phage in growth medium}

Multiplicity of
infection

o (control)

2 phage

4 phage

4 ghosts
Fraction of surviving bacteria
Culture turbidity (arbitrary units)
Amount of cellular enzyme liberated

(\%)

0.3

0.5

0.6

A culture of $E$. coli $\mathrm{B}$, fully induced for $\beta$-galactosidase was growing exponentially in $\mathrm{M}_{9} \mathrm{G}$ medium containing tryptophan, $100 \mu \mathrm{g} . / \mathrm{ml}$. medium, at $37^{\circ}$. T 4 phage or ghosts were added at multiplicities of 2 and 4. After 2 min. of adsorption plaque-forming centres and surviving cells were determined. Ten min. later the cells were chilled, centrifuged and the supernatant analysed for $\beta$-galactosidase content.

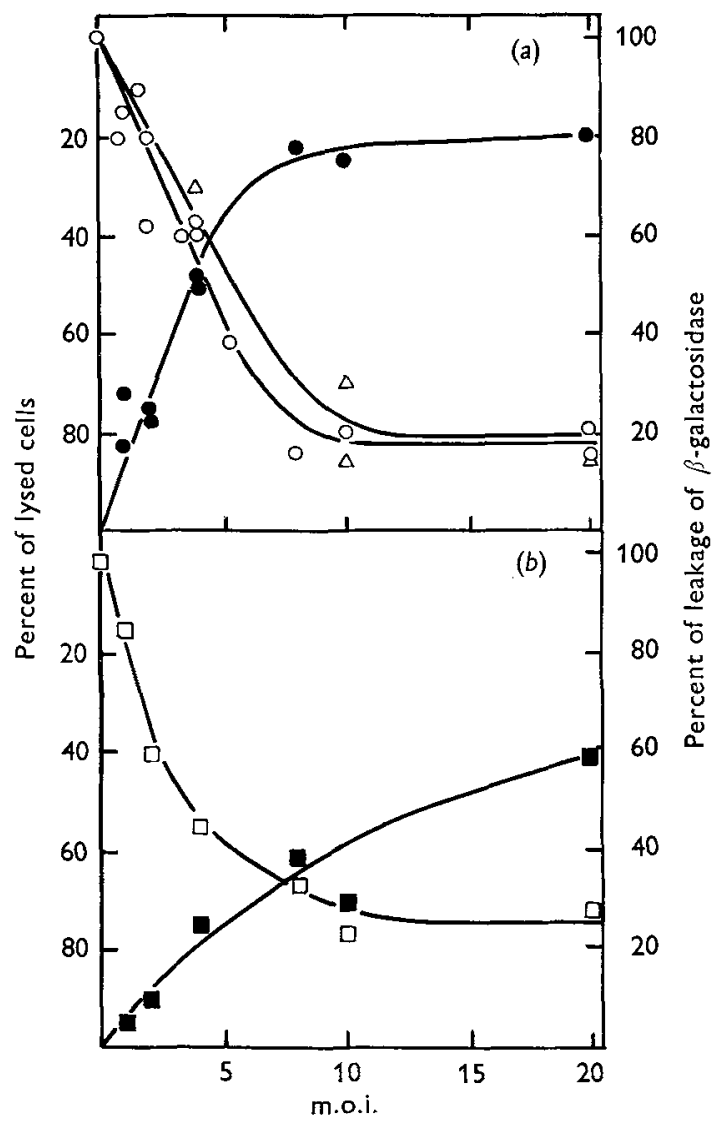

Fig. I. Leakage of $\beta$-galactosidase from $E$. coli $\mathrm{B}$ infected with $\mathrm{T}_{4}$ phage or ghosts in phosphate buffered saline. Exponentially grown cells fully induced for $\beta$-galactosidase were washed and suspended in phosphate buffered saline (containing tryptophan, I00 $\mu \mathrm{g} . / \mathrm{ml}$.) at $37^{\circ}$. The cells were mixed with phage $(a)$ or ghosts $(b)$ at varying input multiplicities. From the assay of plaqueforming centres and surviving bacteria, it was found that at m.o.i. of 4 and higher more than $99 \%$ of bacteria were infected within $2 \mathrm{~min}$. Sixty min. after adsorption, culture turbidity was determined and the supernatant assayed for $\beta$-galactosidase. Percent of cells lysed after infection with: $\mathrm{T}_{4}$ phage $\bigcirc-O$, eGig lysozyme deletion mutant $\triangle-\Delta, T_{4}$ ghosts $\square-\square$. Percent of $\beta$-galactosidase liberated by cells infected with: $\mathrm{T}_{4}$ phage $\longrightarrow, \mathrm{T}_{4}$ ghosts 
slightly higher than that found in the supernatant fraction of the uninfected control sample; $0.6 \%$ of the total $\beta$-galactosidase content which can be released from the cell by complete lysis was liberated by infected cells versus $0.3 \%$ liberated by control samples. Similar results were obtained when ghosts were used. These results sharply contrast with those of Puck \& Lee (1955), who found that about $19 \%$ of the total $\beta$-galactosidase content was released by cells infected with $\mathrm{T} 2$ phage at low multiplicity.

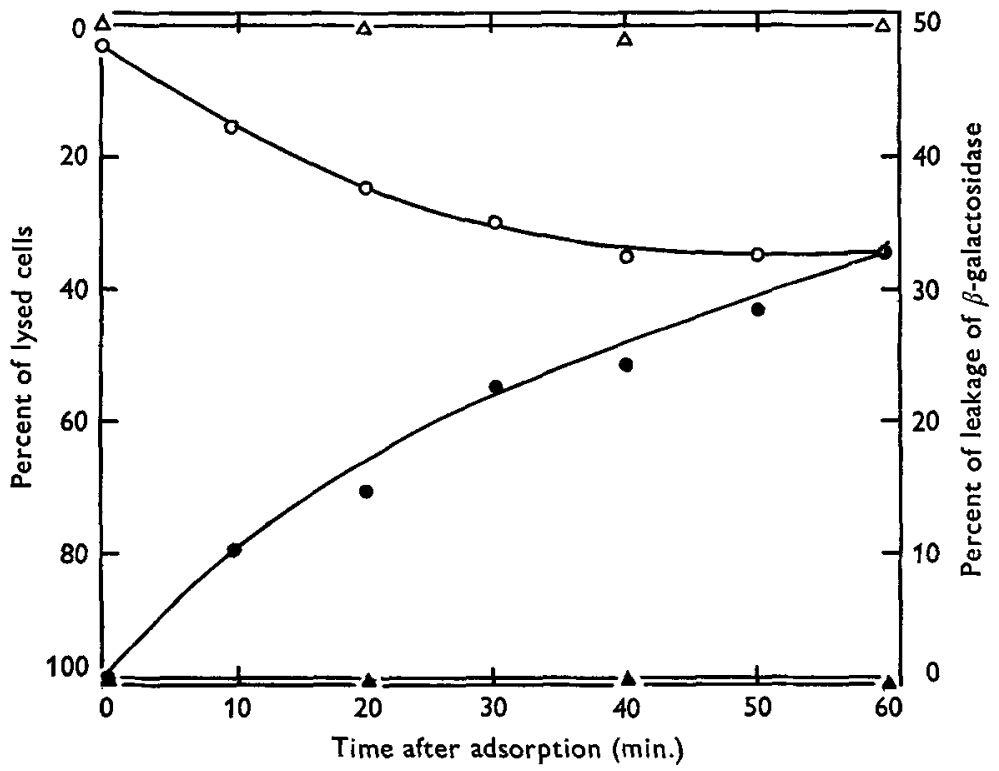

Fig. 2. Time-course of leakage of $\beta$-galactosidase. Cells were grown, washed and suspended in phosphate buffered saline as described in legend to Fig. 1. One portion was incubated at $37^{\circ}$ and the other at $4^{\circ}$. T4 phage was then added at a multiplicity of 4 . Adsorption was $2 \mathrm{~min}$. at $37^{\circ}$ and $20 \mathrm{~min}$. at $4^{\circ}$ (zero time). At zero time and after different times of incubation, culture turbidity and $\beta$-galactosidase in the supernatant fractions were determined. Cell lysis: $\bigcirc-0$, Incubation at $37^{\circ} ; \triangle-\triangle$, incubation at $4^{\circ}$. Leakage of $\beta$-galactosidase: - , at $37^{\circ} ; \mathbf{\Lambda}-$, at $4^{\circ}$.

Leakage of $\beta$-galactosidase from $E$. coli infected with $\mathrm{T}_{4}$ phage in phosphate buffered saline was next examined. $E$. coli в fully induced for $\beta$-galactosidase were mixed in phosphate buffered saline with $\mathrm{T}_{4}$ phage or ghosts at varying input multiplicities and assayed as described in the Methods section. The results of the experiments are illustrated in Fig. I and Fig 2. When $E$. coli with adsorbed phage or phage shockates were incubated at $37^{\circ}$ a gradual decrease in culture turbidity was observed, the extent of the decrease depending on the multiplicity of infection. Thus, at m.o.i. of 4 and to the culture turbidity dropped by 40 and $80 \%, 60$ min. after adsorption, respectively. When drops of the infected culture were examined under the phase contrast microscope a gradual swelling, mainly subterminal, was observed, which progressively enlarged until the bacterial rods were converted to spherical spheroplasts. The spheroplasts slowly faded out. The dissolution of the bacterial culture was accompanied by the appearance of $\beta$-galactosidase in the supernatant fraction. There was a good agreement between the fraction of bacterial culture which lysed and the amount of $\beta$-galactosidase which leaked into the medium. The lysis of the bacterial culture was not accompanied by an increase in the phage titre; on the contrary, phage titre in the lysate was only $1 \cdot 2 \%$ of the original input.

Experiments with the deletion mutant straint $\mathrm{eG}$ I 9 gave results similar in all respects to 
those obtained in experiments with the $\mathrm{T}_{4} \mathrm{~B}$ wild type. In phosphate buffered saline, lysis from without and liberation of $\beta$-galactosidase took place after rapid adsorption of a small number of phage particles on a bacterial cell. These results extend the finding of Emrich \& Streisinger (1968), who showed that bacteria infected in growth medium with high multiplication of the $\mathrm{eG}$ I9 phage lysed soon after infection.

When the phage or their ghosts adsorbed to the cell surface at $4^{\circ}$ and the mixtures were incubated at this temperature there was no drop in the culture turbidity, no conversion of bacterial rods to spheroplasts and no leakage of $\beta$-galactosidase. These results indicate that enzymic activity is involved in lysis from without.

\section{DISCUSSION}

Virus infection can affect the permeability properties of the cell, from without, through digestion of the bacterial cell wall (Delbruck, I940). When a small number of phage particles infects a bacterial cell, digestion of the cell wall starts, and the way in which the cell is eventually disrupted depends now on growth conditions. When the cell is placed in media in which synthesis of cell wall is prevented by the lack of nutrients, or otherwise, digestion of the cell wall proceeds until it no longer withstands the osmotic pressure and after conversion to spheroplasts bursts open, all cellular constituents being liberated into the surrounding medium. Therefore, leakage of $\beta$-galactosidase results from lysis from without, which in phosphate buffered saline is brought about by as few at 2 to 4 phage or their ghosts adsorbed to the bacterial cell. If, on the other hand, the bacterial cell with a small number of phage particles attached to it is placed in favourable growth conditions, the initial slight damage to the cell wall is rapidly repaired so that large molecules ( $\beta$-galactosidase) do not escape into the medium and the cell is finally lysed from within after successful intracellular phage growth.

The nature of the lytic enzyme system which digests parts of the cell wall after phage or ghost adsorption is not clear. Since lysozyme deletion mutant phage is capable of causing lysis from without, it appears that phage lysozyme plays no role in this process. It is also not known whether the lytic activity is associated with the phage or represents murein hydrolase of the host. Murein hydrolases are believed to participate in the synthesis of murein (Shockman, 1965), the component of cell wall intimately associated with the cytoplasmic membrane which is composed of a single macromolecule (for review see Weidel \& Pelzer, 1964). New fragments of cell wall precursors can be inserted into the giant murein molecule only after some pre-existing bonds are broken. This is accomplished by murein hydrolases, probably located in the area of new wall synthesis and the action of which is triggered by DNA replication (Schwarz, Asmus \& Frank, I969). Recent studies (Bayer, I968) have shown that in plasmolysed cells of Escherichia coli $\mathrm{T}$ bacteriophage adsorb to areas where walls and cytoplasmic membranes adhere, i.e. where synthesis of wall substance possibly occurs and where murein hydrolases are located. It is possible, therefore, that adsorption of active or inactive phage particles or their ghosts may trigger a signal which releases the hydrolytic enzyme systems of the host resulting in the degradation of murein and eventually in cell dissolution, if the action of hydrolases is not counteracted by the action of the cell wall synthetases. 


\section{REFERENCES}

ADAMS, M. H. (1959). Bacteriophages. New York: Interscience.

BAYER, M. E. (1968). Adsorption of bacteriophages to adhesions between well and membrane. of $E$. coli. Journal of Virology 2, 346.

DELBRUCK, M. (I940). The growth of bacteriophage and lysis of the host. Journal of General Physiology 23, 643.

EMRICH, J. \& STREISINGER, G. (1968). The role of lysozyme in life cycle of phage T4. Virology $36,387$.

FRENCH, R. C. \& SIMINOVITCH, L. (1955). The action of T2 ghosts on E. coli B. Canadian Journal of Microbiology $\mathbf{x}, 757$.

HEAGX, F. C. (I950). The effect of 2-4 DNP and phage T2 on E. coli. Journal of Bacteriology 59, 367.

HERRIOTT, R. M. \& BARLOW, J. L. (1952). Preparation, purification and properties of E. coli virus T2. Journal of General Physiology 36, 17.

PARDEE, A. B., JACOB, F. \& MONOD, J. (1959). The genetic control and cytoplasmic expression of 'Inducibility' in the synthesis of $\beta$-galactosidase by E. coli. Journal of Molecular Biology $\mathbf{r}, 165$.

PUCK, T. T. \& LEE, L. H. (1955). Mechanism of cell-wall penetration by viruses. II. Demonstration of cyclic permeability changes accompanying virus infection of $E$. coli $\mathrm{B}$ cells. Journal of Experimental Medicine IOI, I5I.

SHOCKMAN, G. O. (1965). Symposium on the fine structure and replication of bacteria and their parts. IV. Unbalanced cell-wall synthesis: autolysis and cell-wall thickening. Bacterial Reviews 29, 345 .

SILVER, S., LEVINE, E. \& SPIELMAN, P. M. (I968). Cation fluxes and permeability changes accompanying bacteriophage infection of E. coli. Journal of Virology $2,263$.

SCHWARZ, M., ASMUS, A. \& FRANK, H. (I969). Autolytic enzymes and cell division of E. coli. Journal of Molecular Biology 4r, 419.

WEIDEL, W. \& PELzER, H. (I964). Bagshaped macromolecules a new outlook on bacterial cell walls. Advances in Enzymology 26, 193.

(Received 5 December 1969) 